\title{
The ring sanctuary of Pömmelte, Germany: a monumental, multi-layered metaphor of the late third millennium BC
}

André Spatzier ${ }^{1, *} \&$ François Bertemes ${ }^{2}$

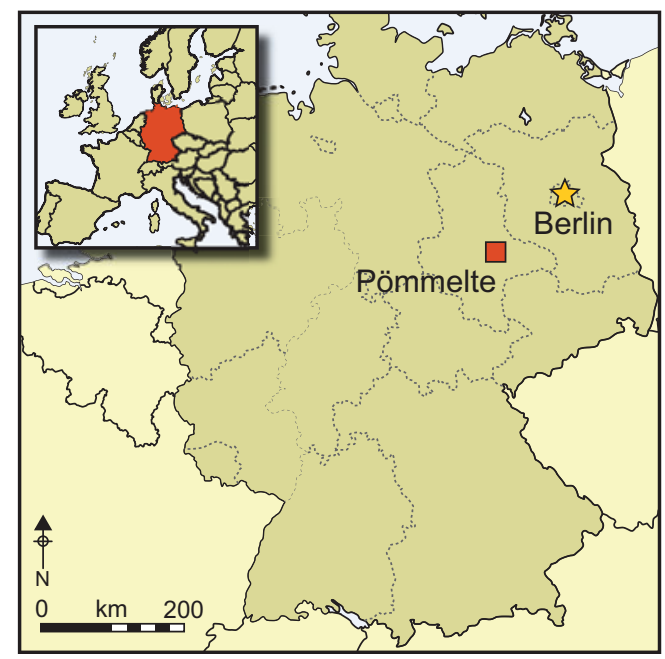

Religion, social identity and social formation processes are topics of great interest to the archaeological community. Regarding the Neolithic and Early Bronze Age monuments of Central Europe, evidence from recent excavations at the Pömmelte enclosure in Central Germany suggests that circular or henge-like enclosures were monumental sanctuaries that served as venues for communal gatherings, ritual activities and performance. We suggest that such enclosures represent complex metaphors, possibly representing cosmological geographies, and that they also played important roles as communal structures in local identity formation and social regulation.

Keywords: Germany, Neolithic, Early Bronze Age, Bell Beaker Culture, Únětice Culture, circular enclosure

\section{Introduction}

The Nebra sky disc is a find of global importance. Its iconography implies intensive observation of the sky and knowledge of complex astronomical phenomena (Meller 2010). The location and context of the disc's deposition in eastern Germany provide insights into the ritual activities of political and cultic authority in the Central European Early Bronze Age. In this region, some 2000 years before, in the early fifth millennium BC, we find the

1 Landesamt für Denkmalpflege Baden-Württemberg, Berliner Straße 12, 73728 Esslingen, Germany

2 Institut für Kunstgeschichte und Archäologien Europas, Martin-Luther-Universität Halle, Emil-AbderhaldenStraße 26-27, 06108 Halle (Saale), Germany

* Author for correspondence (Email: andre.spatzier@rps.bwl.de)

(C) Antiquity Publications Ltd, 2018. This is an Open Access article, distributed under the terms of the Creative Commons Attribution licence (http://creativecommons.org/licenses/by/4.0/), which permits unrestricted reuse, distribution and reproduction in any medium, provided the original work is properly cited. 


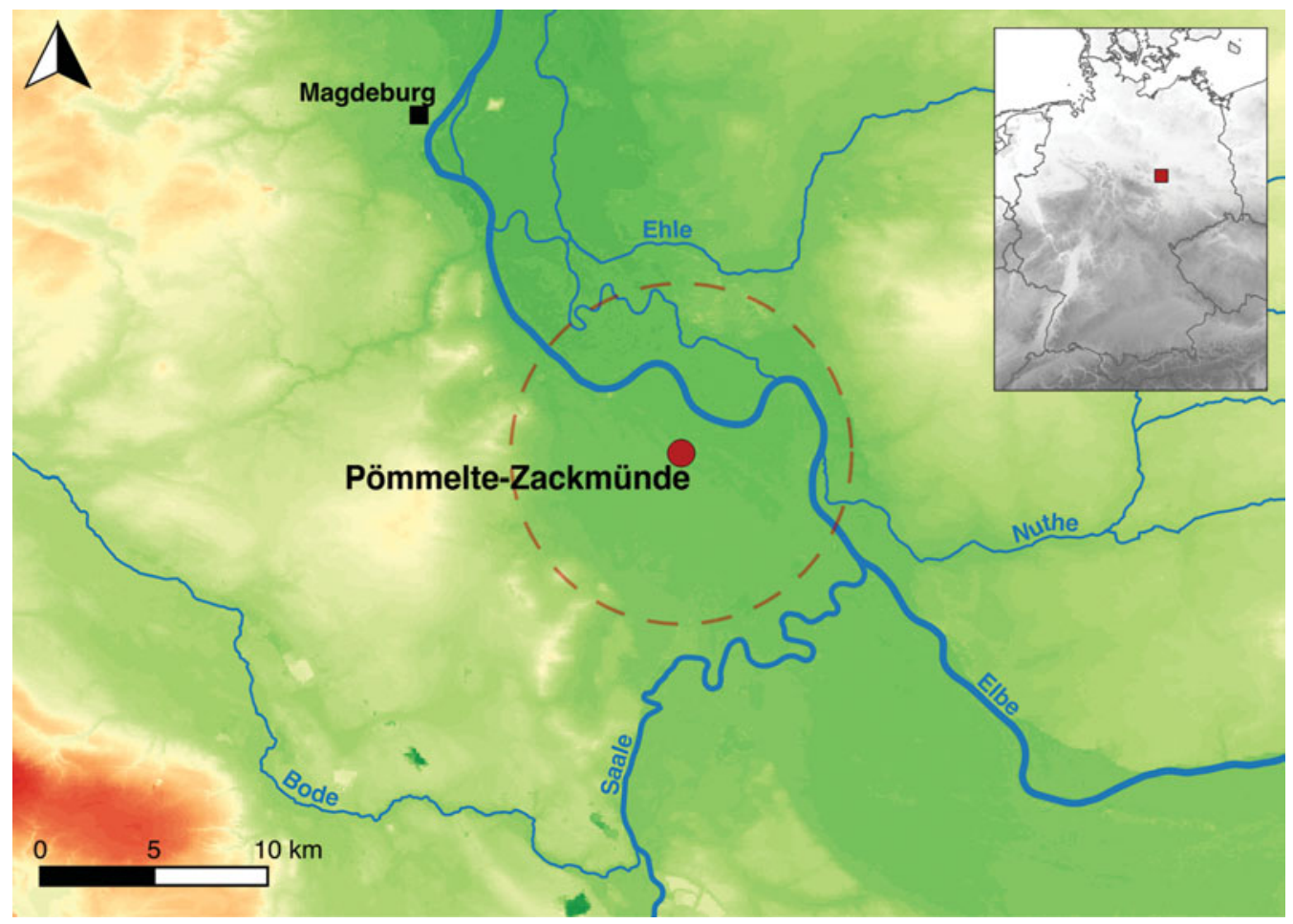

Figure 1. Topographic map of the Pömmelte enclosure location and surrounding micro-region (indicated with a circle) in central Saxony-Anhalt, Germany (base map: DGM 100, LVermGeo LSA, 01/2015).

so-called Kreisgrabenanlagen. These circular enclosures, commonly $40-120 \mathrm{~m}$ in diameter, are defined by ditches with two to four entrances. Based on their layout and the astronomical alignment of their entrances, they have been widely interpreted as sanctuaries (Petrasch 2012: 60-63). The term Kreisgrabenanlagen is, however, misleading, as those monuments also frequently feature concentric rings of pits and posts. In recent decades, evidence has accumulated for comparable enclosures of later dates, including the Early Bronze Age Únětice Culture between 2200 and 1600 BC, and thus into the chronological and cultural context of the Nebra sky disc. Based on the analysis of one of these enclosure sites, recently excavated at Pömmelte on the flood plain of the Elbe River near Magdeburg, Saxony-Anhalt, and dating to the late third millennium BC (Spatzier 2017a; Figure 1), this paper offers new insights into the complex and primarily sacred significance of such monuments within Bronze Age society.

\section{Building sequence and enclosure layout}

While previous aerial and geophysical prospection (Spatzier 2017a: 17-19) indicated the existence of multiple rings at Pömmelte, excavations between 2005 and 2008 revealed a complex architectural layout comprising several concentric circles of posts, pits and ditches, of which the largest was approximately $115 \mathrm{~m}$ wide (Figure 2 ). The central open spacewith a diameter of around $47 \mathrm{~m}$ - was encircled by two rings of loosely spaced posts. Moving (C) Antiquity Publications Ltd, 2018 


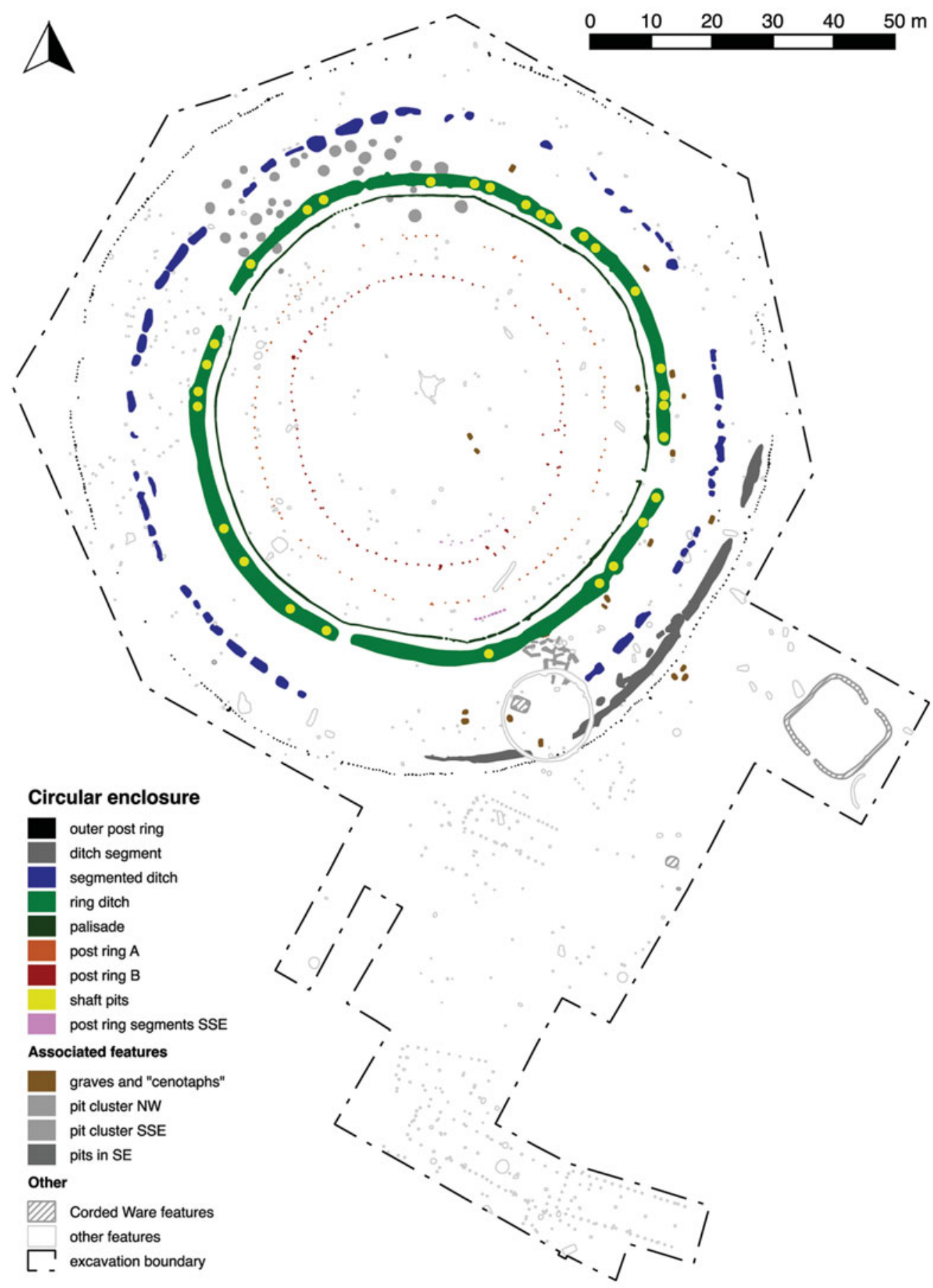

Figure 2. Plan of the excavations in Pömmelte-Zackmünde between 2005 and 2008 (plan by André Spatzier).

(C) Antiquity Publications Ltd, 2018 
outwards, a palisade confined the interior and ran along the inside edge of a ring ditch, outside of which (as deduced from the backfilling of the ditch) was a bank, probably of discontinuous segments. Next came a ring of elongated pits, probably once forming sections of a segmented ditch, and then a shallow ditch dug only in the south-eastern quarter. Finally, a ring of closely spaced posts defined the enclosure's outer perimeter.

Two main entrances oriented east-south-east and west-north-west, and two side entrances oriented south-south-west and north-east formed significant architectural elements marked by interruptions or distinctive symmetrical post settings (Figure 2). These post settings existed only along the main entrance axes in each ring, thereby facilitating direct passage through the monument connecting the interior with the surrounding landscape. The most elaborate constructions were apparently along the east-north-east axis and indicate that this was the main corridor used to enter or leave the enclosure. In contrast, the side entrances did not connect all the ring zones and perhaps only allowed passage from one ring zone to the next.

Irregularities in the layout at Pömmelte suggest a multi-phase construction. The main entrances of each of the inner rings, the palisade and the ring ditch show precise axial alignments, although the interruption in the ditch for the east-south-east entrance is shifted slightly northwards. The main entrances of the outer post ring and the gaps in the segmented ditch and the south-eastern curved ditch are also axially aligned but slightly shifted southwards. The alignment shift of the main entrance axes suggests that the inner and outer circles may represent something akin to building units or phases. Furthermore, the ring ditch initially may have had three additional interruptions to the south-east, southsouth-east and north-north-west, which were dug out or removed later.

The precision of the monument's layout illuminates the building process. The ring ditch is the most geometrically accurate of all the circles; the accuracy of the other rings decreases slightly towards both the interior and the exterior (Figure $2 \&$ Table 1). Presumably the laying out of the ring ditch worked from a point selected as the centre for the enclosure. Subsequently, the ring ditch was used as the reference to lay out the inner and outer rings, with the exception of the innermost. The latter seems to have comprised a northern semiellipse and a southern semi-circle. This is reminiscent of Woodhenge and the Stonehenge bluestone oval. These can be interpreted as two semicircles possibly representing D-shaped "meeting houses" (Parker Pearson 2013: 336). At Pömmelte, the two distinct parts of the innermost post ring suggests the possibility of two building phases.

Evidently, the archaeological plan of the enclosure demonstrates a superimposition of construction phases. The ring ditch was probably dug c. $2300 \mathrm{BC}$, but, for now, it is impossible to date the erection of the post rings. There is, however, evidence to suggest that, at one stage, all the circles existed contemporaneously. When the post rings were deconstructed by extracting the timber posts, offerings were deposited in the postpipes. Two radiocarbon dates on bone from such 'final' deposits found in the innermost post ring (B) correlate with the youngest dates that are stratigraphically older than a massive layer (in terms of thickness and representation around the ditch) containing wood ash in the ring ditch. Thus, at the end of the enclosure's main occupation phase, the inner post rings, the palisade, ring ditch and bank may have existed simultaneously with each other. Following this, they were dismantled, the timbers burnt and the ash backfilled into the ring ditch.

(C) Antiquity Publications Ltd, 2018 
Table 1. Geometry of the Pömmelte enclosure's individual rings.

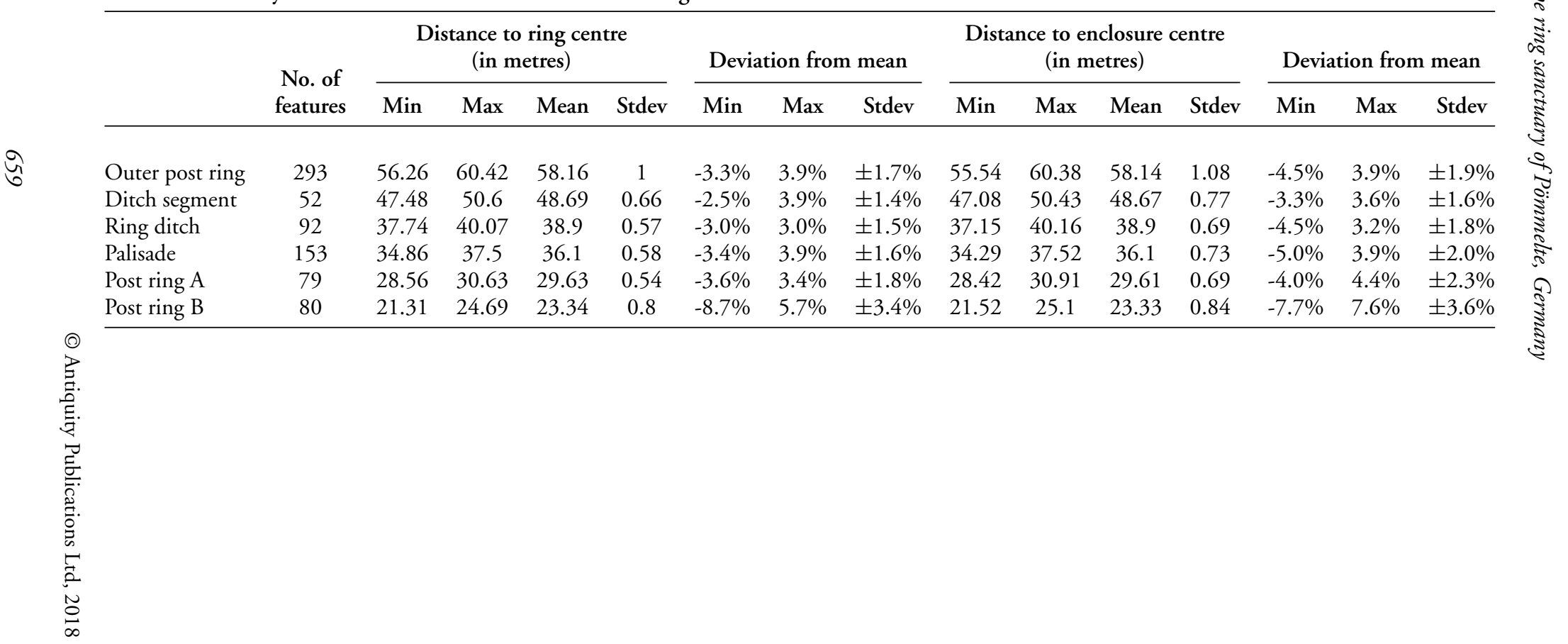

\section{Research}


This may also be true for the outer post ring and the adjacent curved ditch (the grey ditch segment on Figure 2), as radiocarbon dating of bone from the latter correlates with the predeconstruction dates' (see below). With regard to the segmented ditch, two charcoal dates fit into this chronology, but one bone date is the youngest for the enclosure.

In summary, a general building sequence can be suggested for the Pömmelte monument. The first phase involved defining the enclosure's centre and marking out the ring ditch, the latter then serving as a reference for subsequent construction. The outer and two inner post rings probably represent subsequent building phases; the inner rings were probably constructed first. Prior to the deconstruction event, the inner rings-and perhaps all of the rings - coexisted. The enclosure was dismantled around $2050 \mathrm{BC}$; the timbers were burnt, the bank flattened and the ditches and pits backfilled. Subsequently, a few features were dug into the former ring ditch and along the outer rings.

\section{Time and people}

The chronology and the cultural sequence of the Pömmelte enclosure are determined by finds recovered from the ring ditch and from 29 shaft-like pits dug into it. The relative sequence of these features combined with 25 radiocarbon dates allow for the differentiation of three distinct occupation phases. Stratigraphically, at least six of the shafts were dug into the unsilted ditch. The majority (i.e. at least 15), however, were dug when the ditch had partially silted up, and at least one shaft was dug after the backfilling event, with which almost all finds deriving from the ring ditch are associated. Although the stratigraphy of a few of the shafts remains ambiguous, this does not affect the general interpretation: two main phases (I and II) of enclosure occupation, and a phase of abandonment/re-use. Two Bayesian models were processed using OxCal 4.2.4 (IntCal13 calibration curve; Bronk Ramsey 2009; Reimer et al. 2013), which are consistent within a range of six years (Table 2; Spatzier 2017a: 251-54).

The chronology and cultural context of the site can be reconstructed by combining Bayesian modelling, stratigraphy and the cultural attribution of the finds (Figure 3; dates at $1 \sigma$-precision). The main occupation began at $2321-2211 \mathrm{cal} \mathrm{BC}$, with the stratigraphically earliest features containing exclusively Bell Beaker finds. Bell Beaker ceramics continue after 2204-2154 cal BC (boundary occupation I/II), although they were probably undecorated, but are now complemented by Únětice Culture (and other Early Bronze Age) types. At this time, pots with features common to both cultures predominate. Only contexts dating to the late main occupation phase (late phase II) and thereafter contained exclusively Únětice Culture finds. Evidently, the bearers of the Bell Beaker Culture were the original builders of the enclosure. During a second phase of use, Final Neolithic and Early Bronze Age cultures coexisted and intermingled. The material remains, however, should not be taken as evidence for successive groups of differing archaeological cultures, but as witnesses to a cultural transition from the Bell Beaker Culture to the Unětice Culture (Spatzier 2015). The main occupation ended 2086-2021 cal BC with the deconstruction of the enclosure; Bell Beaker finds are now absent. Finally, a few features (among them one shaft) and radiocarbon dates attest the sporadic re-use of the site in a phase of abandonment/re-use that ended 16361488 cal BC.

(C) Antiquity Publications Ltd, 2018 
Table 2. Posterior probabilities of two Bayesian models based on the ring ditch's stratigraphy and supplemented by correlating features belonging to the enclosure (for details, see Spatzier 2017a: 245-54).

\begin{tabular}{|c|c|c|c|c|c|}
\hline & & \multicolumn{2}{|c|}{$\begin{array}{c}\text { Model 'occupation var. 1' } \\
\text { (Amodel: 120.7) }\end{array}$} & \multicolumn{2}{|c|}{$\begin{array}{l}\text { Model 'occupation var. 2' } \\
\text { (Amodel: 92.2) }\end{array}$} \\
\hline & & $\begin{array}{l}\text { Modelled } \\
\text { dates } \\
\text { cal } 1 \sigma\end{array}$ & $\begin{array}{c}\text { Modelled } \\
\text { dates } \\
\text { cal } 2 \sigma\end{array}$ & $\begin{array}{c}\text { Modelled } \\
\text { dates } \\
\text { cal } 1 \sigma\end{array}$ & $\begin{array}{c}\text { Modelled } \\
\text { dates } \\
\text { cal } 2 \sigma\end{array}$ \\
\hline \multicolumn{2}{|l|}{ Start occupation } & $\begin{array}{c}2321-2216 \\
\text { cal BC }\end{array}$ & $\begin{array}{l}2449-2202 \\
\text { cal BC }\end{array}$ & $\begin{array}{l}2320-2211 \\
\text { cal BC }\end{array}$ & $\begin{array}{l}2476-2160 \\
\text { cal BC }\end{array}$ \\
\hline \multicolumn{6}{|l|}{ Main occupation } \\
\hline \multirow{2}{*}{$\begin{array}{l}\text { Occupation I (4 } \\
\text { dates) }\end{array}$} & Span & 9-90 years & $0-155$ years & $0-64$ years & $0-144$ years \\
\hline & Interval & $23-153$ years & $0-278$ years & $0-132$ years & $0-280$ years \\
\hline \multicolumn{2}{|c|}{ Boundary occupation I/II } & $\begin{array}{c}2203-2154 \\
\text { cal BC }\end{array}$ & $\begin{array}{l}2235-2075 \\
\text { cal BC }\end{array}$ & $\begin{array}{c}2204-2156 \\
\text { cal BC }\end{array}$ & $\begin{array}{l}2244-2145 \\
\quad \text { cal BC }\end{array}$ \\
\hline \multirow{2}{*}{$\begin{array}{l}\text { Occupation II (13 } \\
\text { dates) }\end{array}$} & Span & $68-147$ years & $4-162$ years & $68-153$ years & $23-184$ years \\
\hline & Interval & 113 years & 143 years & 108 years & 144 years \\
\hline \multicolumn{2}{|c|}{ Interval main occupation } & $\begin{array}{l}157-281 \\
\text { years }\end{array}$ & $\begin{array}{c}105-392 \\
\text { years }\end{array}$ & $\begin{array}{l}145-280 \\
\text { years }\end{array}$ & $\begin{array}{c}411 \\
\text { years }\end{array}$ \\
\hline \multicolumn{2}{|c|}{ Boundary deconstruction/re-use } & 2086-2021 & 2131-2009 & 2092-2024 & $2127-2010$ \\
\hline \multirow[t]{2}{*}{$\begin{array}{l}\text { Abandonment/re-use } \\
\text { (8 dates) }\end{array}$} & Span & $\begin{array}{l}353-478 \\
\text { years }\end{array}$ & $\begin{array}{c}293-543 \\
\text { years }\end{array}$ & $\begin{array}{c}353-483 \\
\text { years }\end{array}$ & $\begin{array}{c}292-548 \\
\text { years }\end{array}$ \\
\hline & Interval & $\begin{array}{c}415-582 \\
\text { years }\end{array}$ & $\begin{array}{c}342-702 \\
\text { years }\end{array}$ & $\begin{array}{c}417-586 \\
\text { years }\end{array}$ & $\begin{array}{c}341-712 \\
\text { years }\end{array}$ \\
\hline \multicolumn{2}{|l|}{ End enclosure } & $\begin{array}{l}1635-1488 \\
\text { cal BC }\end{array}$ & $\begin{array}{l}1707-1381 \\
\text { cal BC }\end{array}$ & $\begin{array}{l}1636-1488 \\
\text { cal BC }\end{array}$ & $\begin{array}{l}1704-1368 \\
\text { cal BC }\end{array}$ \\
\hline \multicolumn{2}{|c|}{ Interval occupation/re-use } & $\begin{array}{l}622-819 \\
\text { years }\end{array}$ & $\begin{array}{l}\text { 547-976 } \\
\text { years }\end{array}$ & $\begin{array}{c}620-826 \\
\text { years }\end{array}$ & $\begin{array}{c}540-1009 \\
\text { years }\end{array}$ \\
\hline
\end{tabular}

\section{Ritual disposal of paraphernalia and offerings}

The 29 shaft-like pits dug into the ring ditch were used to deposit carefully selected objects, and are key to the interpretation of the meaning of the enclosure. The shafts' infilling and the characteristics of the local soil substrate indicated that the pits were dug and then quickly backfilled. Individual artefact deposits therefore must have been brief events that occurred in a very consistent manner for centuries. Based on the relationships of the shafts to one another and to the enclosure's other features, and on the objects deposited, three distinct categories of deposition can be identified that form a multi-step 'shaft-pit sequence' of depositions. Detailed analysis of intentional, as well as possibly unintentional, depositions (Figure 4) allows for the deduction of a general scheme of deposition (Figure 5).

The 29 shafts were dug for category 1 deposits (DepCat 1 on Figure 4) that were found in the shaft's lowest sections-i.e. the primary stratigraphic context. The objects deposited were located within or above cylindrical containers of unpreserved organic material, such as baskets, that are evident from the shaft's fill (see Figure 5). The deposits include ceramic 


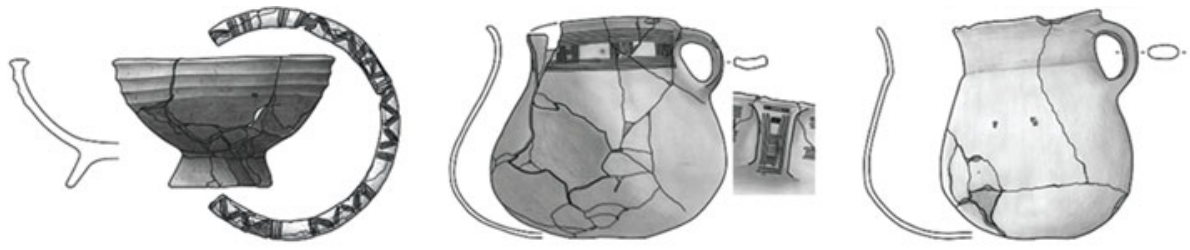

Bell Beaker Culture (BBC)

Únětice Culture (ÚC)

"Giant Beaker" Influence

Site Chronology (BBC - ÚC)

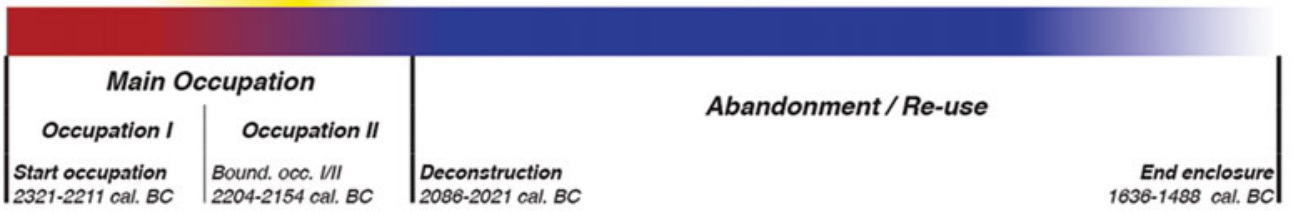

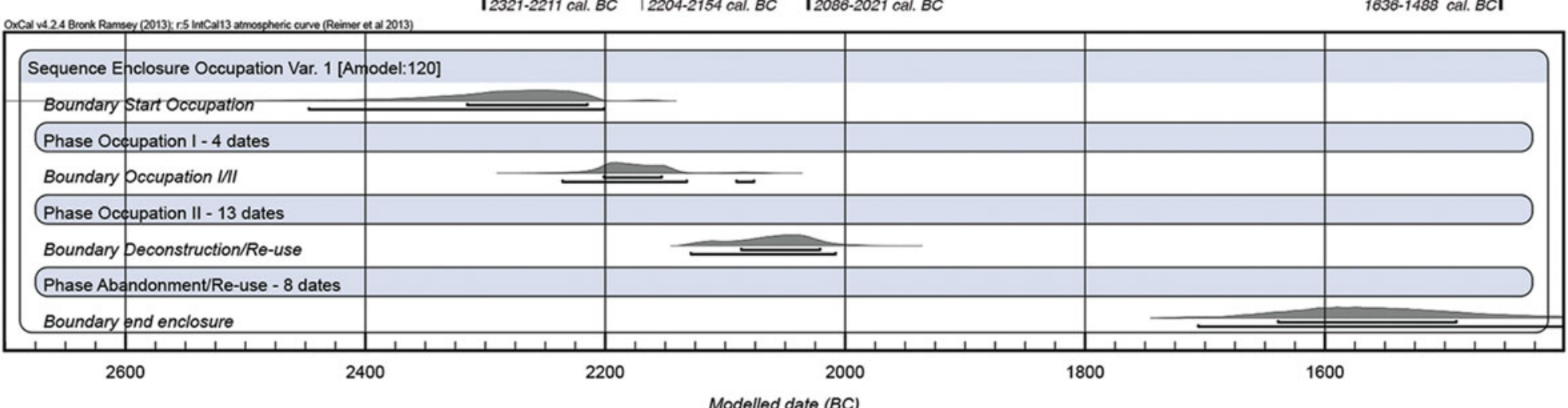

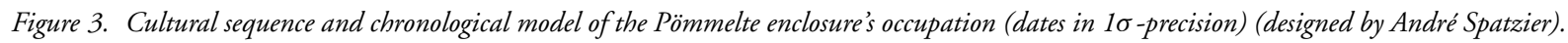



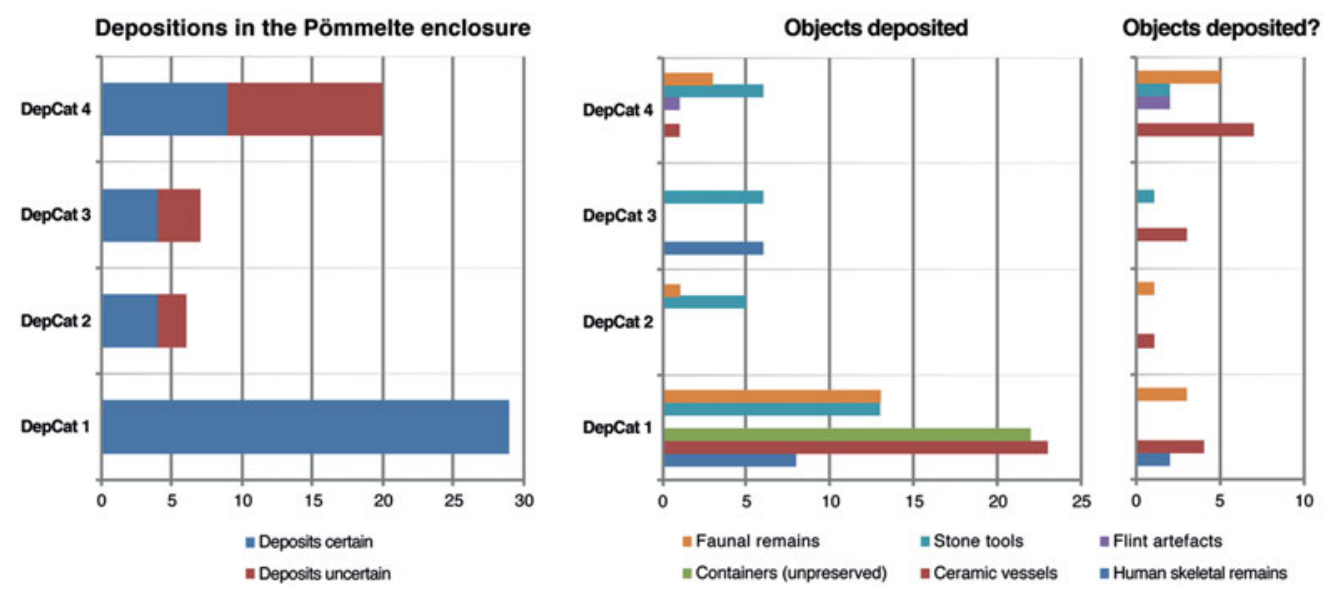

Figure 4. Frequency of deposits and objects of certain and uncertain depositional character (graphs by André Spatzier).
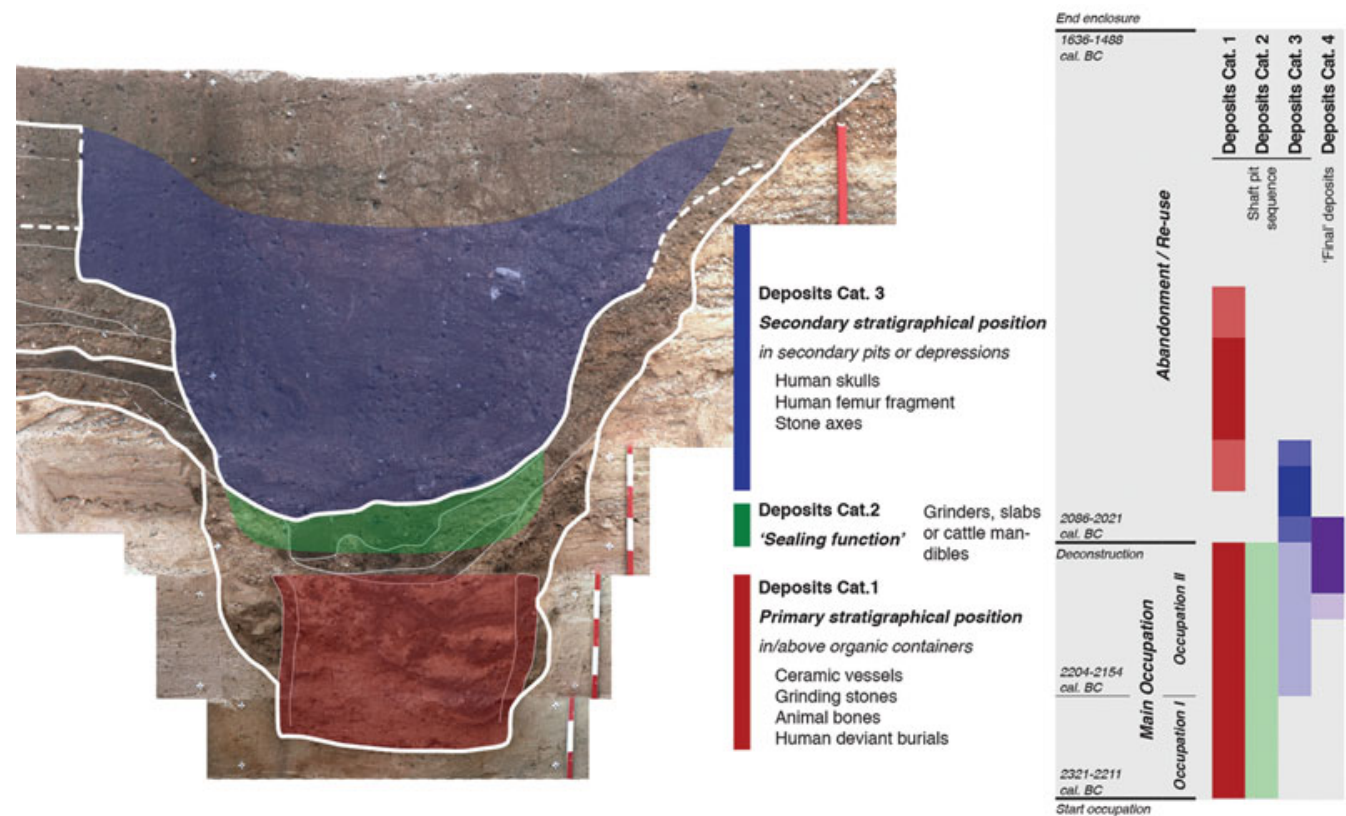

Figure 5. Scheme of the Pömmelte 'shaft-pit sequence' of depositions and their chronology (dates in 1 $\sigma$-precision) (designed by André Spatzier)

vessels (predominantly drinking vessels, such as beakers, jugs and cups), animal bones (often showing cut or chop marks), saddle querns (either complete mills, grinders or slabs), and a few stone axes. Furthermore, deviant burials_identified as children, juveniles and females, of which four exhibited severe perimortem skull trauma and rib fractures (Stecher \& Alt in press) - were found in positions suggesting that they had been thrown into the shafts. It remains unclear whether these individuals were ritually killed or if their death resulted from

(C) Antiquity Publications Ltd, 2018 
intergroup conflict, such as raiding. Nevertheless, the victims of gender-specific violence, along with the corpses of the other individuals, were meaningful to the ritual activities related to the shafts (Spatzier 2017b).

Five shafts contained category 2 deposits (DepCat 2) in the uppermost gravel fills, comprising cattle mandibles and grinders or slab stones placed with their grinding side facing downwards. As the pits must have silted up or been backfilled quickly, the items were deposited shortly after the category 1 depositions and may have functioned to signal the closure of activities initially associated with the shafts.

The category 3 deposits (DepCat 3 ) were made up to 300 years after the shafts had been backfilled or had silted up completely. This suggests some surface marking of the shafts' locations, long-term knowledge concerning former depositions and traditional behaviour. Above four shafts-i.e. in secondary stratigraphic contexts-human crania, a human femur fragment and stone axes were deposited-twice in pits dug into the shaft infill. Although secondary pits above three other shafts contained no finds, they may have held deposits that have not survived.

Intentional fragmentation of material is a feature common to all depositions. This is supported by statistical analysis of the ceramic vessels from the category 1 deposits (Spatzier 2018), and by damage found on the stone tools and human remains. Large sherd sizes and the general completeness of the vessels, the splintering of axe cutting edges and the querns with missing corners probably all resulted from intentional, moderate and symbolic destruction. Damage to the deviant burials in the form of perimortem trauma and the removal of limbs prior to burial is obvious, but the motives for such destruction are harder to establish.

Stratigraphy and radiocarbon dating provide a firm chronology for the shaft depositions. The category 1 and 2 deposits occurred throughout the enclosure's main occupation phases (I \& II) — spanning 165-345 years—and at least once after this period. While one category 3 deposit dates to the phase of abandonment/re-use, the others correlate stratigraphically with occupation phase II. They were most probably deposited close to or with the deconstruction of the enclosure around $2050 \mathrm{BC}$, an event indicated by a massive ash layer (in terms of thickness and extent) in the ditch and the placement of offerings into the post rings. These 'final' category 4 deposits (DepCat 4), comprising pottery fragments, cattle bones and stone axes, were inserted not into the shafts but rather into the postpipes after the timbers had been extracted. Hence, they complement the complex deposition practices evident in the 'shaft-pit sequence'.

Rappaport (1999: 32-50) and Bell (1997: 139-69), although using different terminology, agree that the main characteristics of rituals and ritual-like activities are 'encoding by others than the performers' (after Rappaport, i.e. by 'rule-governance' and 'traditionalism' after Bell), formality, invariance and performance (Bell also adds 'sacral symbolism'). With restrictions regarding the performance criterion, these characteristics are all reflected at the Pömmelte enclosure. In particular, the 'shaft-pit sequence' reveals a distinct and recurrent pattern that persisted for centuries. Its three categories of depositions clearly had diverse and discrete meanings, and can best be explained by formalised, relatively invariant and rule-based practices handed down as traditions over several generations. Thus, the depositional acts can be identified as rites, and the patterns reflected by the deposited (C) Antiquity Publications Ltd, 2018 
objects suggest that they are the remnants of ritual activities. As these objects had been used as ritual paraphernalia, taboo demanded their destruction and permanent disposal as 'sacred waste'.

\section{Layers of space-and-meaning associations}

Rappaport (1999: 37) states that "unless there is a performance there is no ritual". It can therefore be concluded that the Pömmelte enclosure was a place intended for performance. Performative displays_ritual or profane-and social functions are both reflected in Pömmelte's architectural 'master plan'. The arrangement of concentric ring zones and the two main entrances focused attention on the central open space. The palisade and the bank reinforced this effect dramatically, acting as barriers that visually and acoustically separated the interior and the depositional ditch zone from the outer zone and the surrounding landscape. Access to these ring zones was restricted and channelled by the main, side and additional entrances.

From the functionality of this 'master plan', a model of hierarchical spatial organisation with four zones, I-IV, can be deduced (Figure 6). The model presupposes that all rings existed simultaneously. This can be assumed for the end of the main occupation and it would also apply if the outer rings represent a separate construction phase. Important features of this model are the increasing regulation of access, the focusing of attention, the induction of meaning (e.g. mental or emotional), the formation of identity and symbolicprobably sacred-meaning, and, with proximity to the centre of the monument, the decreasing publicness of the (performative) activities and the number of persons involved therein.

How the above-ground structures possibly influenced perception may reveal another layer of meaning that highlights social functions related to ritual. While zone I was disconnected from the surroundings by a 'semi-translucent' post-built border, zones II/III were separated from the outside world by a wooden wall (i.e. the palisade), and zone III probably separated individuals from the crowd gathered in zone II. Accessing the interior or centre therefore meant passing through transitional zones, to first be secluded and then segregated. Exiting the structure meant re-integration and re-connection. The experience possibly induced when entering and leaving the monument reflects the three stages of 'rites of passage' described by van Gennep (1909): separation, liminality and incorporation. The enclosure's outer zone(s) represents the pre- and post-liminal phase; the central area, the liminal phase. Seclusion and liminality in the interior promoted a sense of togetherness, which can be linked to Turner's “communitas" (1969: 132-33). We might therefore see monuments such as the Pömmelte enclosure as important communal structures for social regulation and the formation of identity.

Further layers of meaning arise from the spatial distributions of the finds and features. Analysis of dispersion densities of the faunal remains and ceramics, for example, reveals find 'hot spots' and areas of low accumulation (Figure 7: 1-2). For the pottery, these patterns correlate with sherd size (Spatzier 2018): the hot spots correspond with large sherds (in the south-south-west, north-east and south-east), the areas almost devoid of finds with very small sherds (in the north-north-west, east-north-east and south-south-east). These 


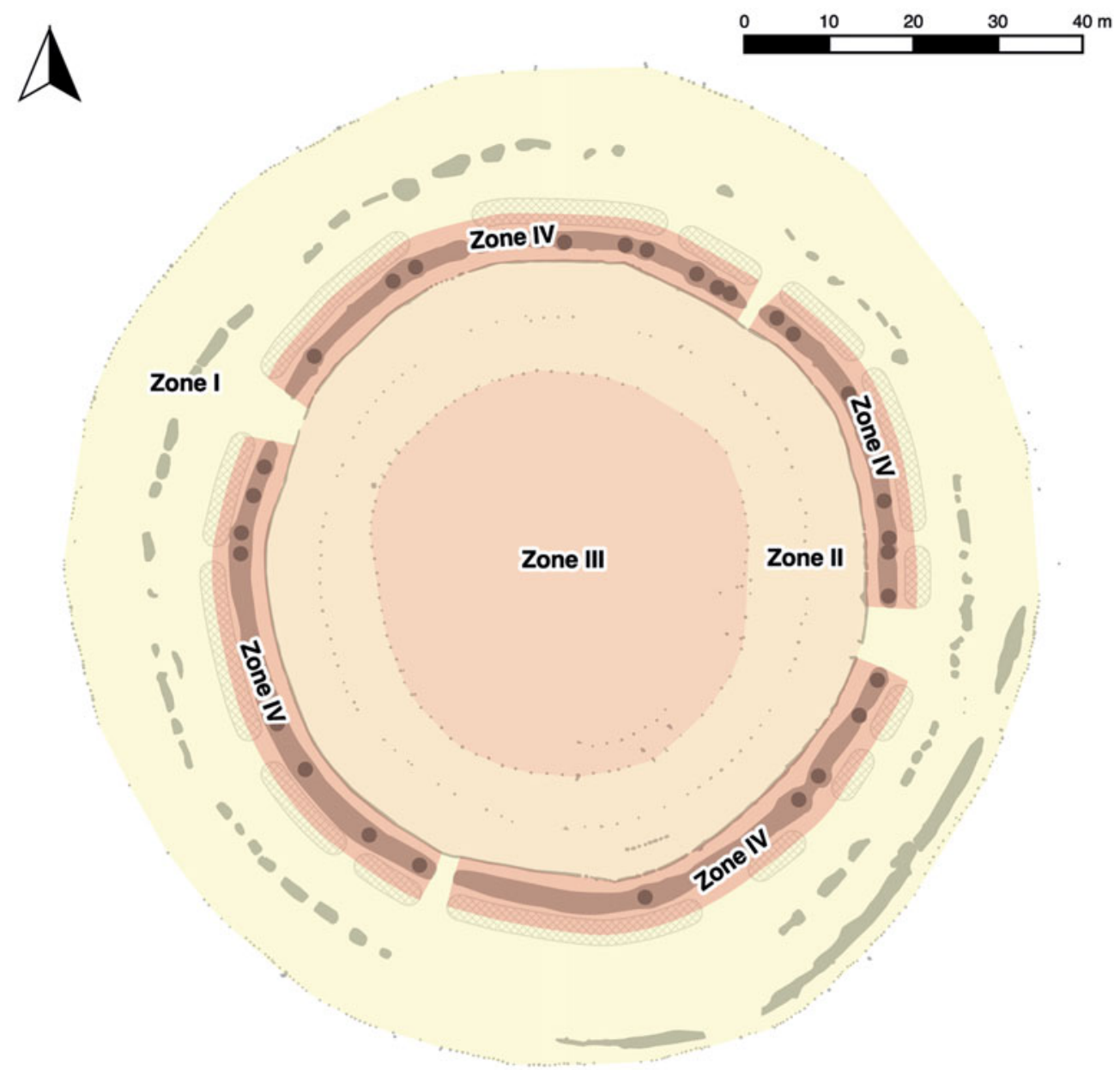

Zone I public, easily accessible space for a wide range of activities

Zone II restricted access, area that provided space for many persons participating as the audience in 'public' performative activities

Zone III central stage-like space for 'public' ritual performance and other activities, access for performers and persons directly involved

Zone IV space for non-public ritual activities, in particular the deposition of paraphernalia, sacrifices and votive offerings

Figure 6. Model of the spatial organisation of the Pömmelte enclosure (designed by André Spatzier).

spatial patterns may reflect zones of high and low activity. Furthermore, the areas around the narrow interruptions in the ditch were the main zones of activity or discard, whereas no objects were discarded deliberately near the main entrances-or these areas were perhaps cleaned up.

The distribution of certain types of finds and features facilitate more tangible interpretations. Stone axes and querns derive exclusively from deliberate depositions, (C) Antiquity Publications Ltd, 2018 

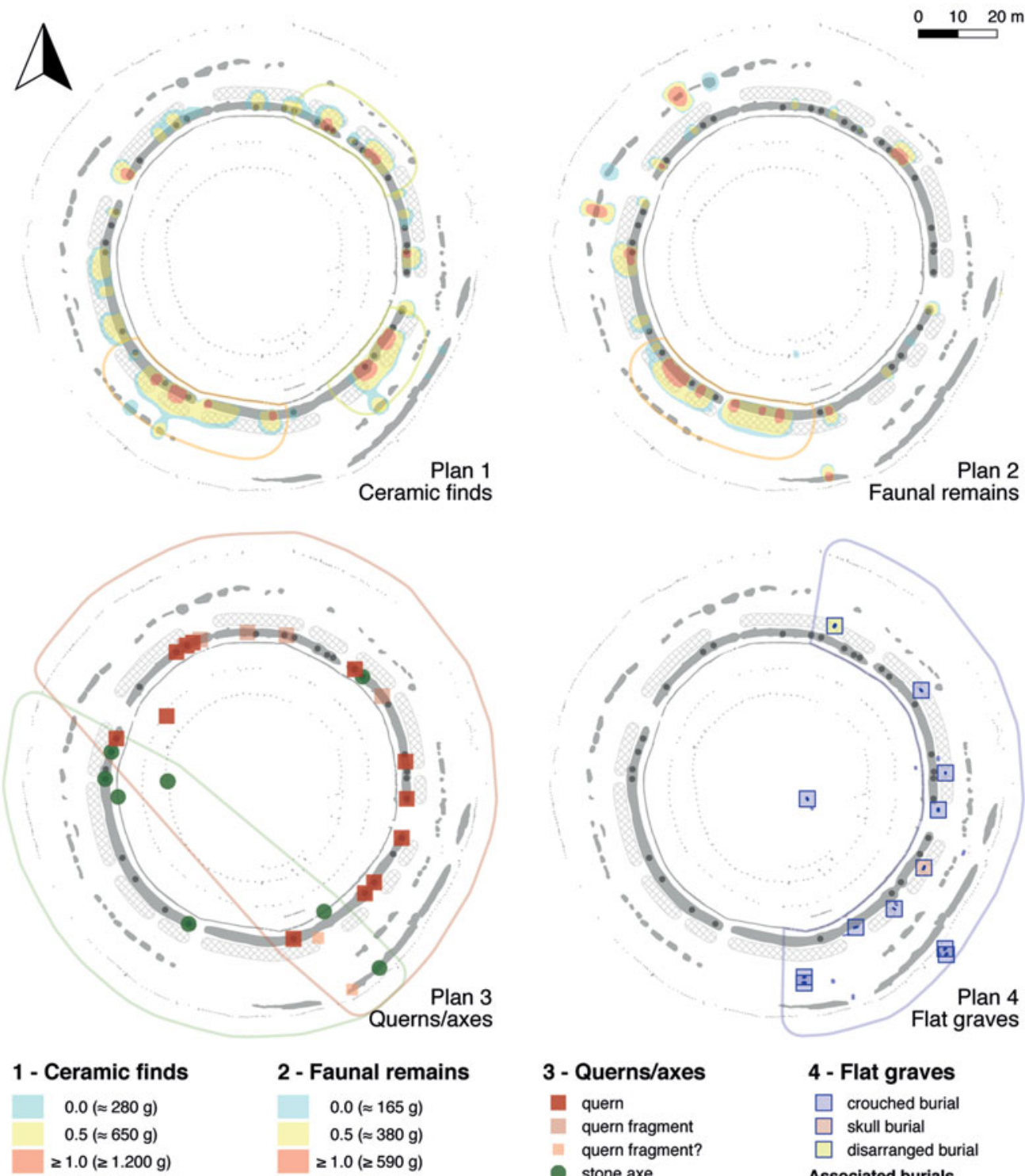

\section{2 - Faunal remains}

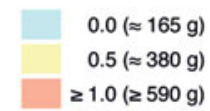

IDW interpolation of classes of standardized weight (finds deriving from shaft pits excluded)

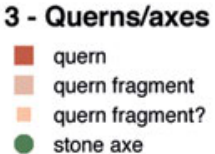

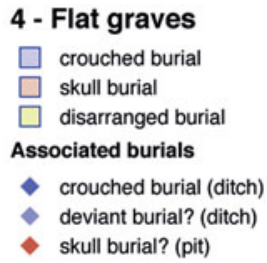

\section{- Flat graves}

$\square$ crouched burial

skull buria Associated burials

crouched burial (ditch)

skull burial? (pit)

Figure 7. Distribution of 1) the ceramic finds; 2) faunal remains; 3) querns and stone axes; and 4) flat graves in the Pömmelte enclosure (designed by André Spatzier).

and therefore testify to intentional associations of space and meaning: querns were found in the enclosure's north-eastern sectors, and stone axes in the south-western half (Figure 7: 3). Querns are symbols of femaleness, fertility, life and death, transformation and subsistence (Peacock 2013: 162-78; Watts 2014). Axes are associated with maleness,

(C) Antiquity Publications Ltd, 2018 
as they represent status insignia linked to high-ranked male warriors in the Corded Ware and Únětice Cultures (e.g. Wiermann 2001: 90-92; Kraus 2006: 32-33, 268-72, 43135 \& 451; Vandkilde 2006: 417; Meller 2017). Thus, the contrasting distributions of querns and axes at Pömmelte may symbolise opposite yet complementary gendered spheres related to fertility and reproduction. Interestingly, quern fragments derive exclusively from non-depositional contexts in the same area as the intentionally deposited querns. This demonstrates that material culture patterning of structured deposits (see Garrow 2012 and discussion thereafter) in Pömmelte most probably results from ritualised practices, rather than from 'everyday' activities.

Furthermore, the enclosure was a socially indicative burial ground (i.e. a place signalling social status). Thirteen simple flat grave inhumations, including skull and disarticulated burials, clearly contrast with the shaft burials of children, juveniles and females. Males aged 17-30 years (Stecher \& Alt in press) were buried in concordance with Bell Beaker and Únětice mortuary customs for men, although adapted to the circular layout (Figure 7: 4). Considering ring ditches as signifiers of high-status burials in the Final Neolithic and perhaps the Early Bronze Age, and Turner's (1969) concept of liminality, these graves can be interpreted as ad sanctos inhumations (i.e. inhumations near or in a sacred site) of men of extraordinary social status (Spatzier 2017b). The general orientation of these burials to face east and their location in the enclosure's eastern half reflect the association of death and sunrise, symbolising belief in reincarnation or an afterlife.

The Nebra disc and Nordic Bronze Age iconography indicate that the sun was a major element of Neolithic and Bronze Age cosmology (e.g. Kaul 2004; Bertemes 2009). At Pömmelte it is not only expressed in 'formal' burials of privileged men, but is also emphasised by the solar alignment of the main entrances. It is not as straightforward to use the enclosure's centre (e.g. the innermost ring has multiple centres) for astronomical analysis, but doing so demonstrates that these entrance axes were oriented to sunrise and sunset midway between the solstices and equinoxes (Schlosser in press). Considering imprecisions in pre- and protohistoric periods caused by astronomical, geographic and environmental factors, Schlosser relates these dates to Celtic seasonal festivals that celebrated the transition of the seasons, the harvest, or commemoration of the dead. This adds a further level of meaning to Pömmelte: as a monument for ceremonies linked to calendrical rites and seasonal feasting.

\section{Synthesis-sanctuary and warrant}

The focusing of attention, a boundary zone between this world and the next, and participation and offering are three indicators of religious activity in the archaeological record, particularly if "repeated actions of symbolic nature which are directed [...] towards [...] transcendent forces" can be detected (Renfrew 1994: 51-52). As outlined above, the depositional sequence alone is sufficient to identify the Pömmelte enclosure as a place for ritual. By integrating multiple criteria (Spatzier 2017a: tab. 10) into a polythetic synthesis, the enclosure can be interpreted as a monumental sanctuary.

The layers of meaning described above are crucial in confirming this hypothesis. They are evident from the combination of spatial associations and the metaphorical meaning of (C) Antiquity Publications Ltd, 2018 
Ceramic Finds / Faunal Remains Density

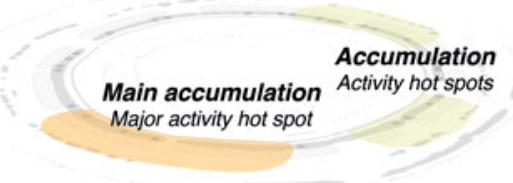

Querns vs. Axes - Gendered Spheres

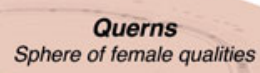

Stone axes

Sphere of male qualities

Flat Graves - Status Cemetery

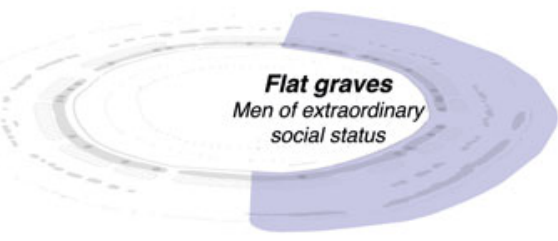

Solar Alignment - Seasonal Rites

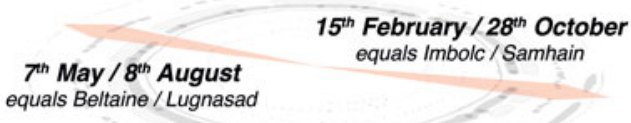

Zonal Structure - Focus, Identity, Social Regulation

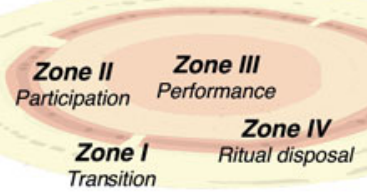

Circular Architecture - Monumental Sanctuary

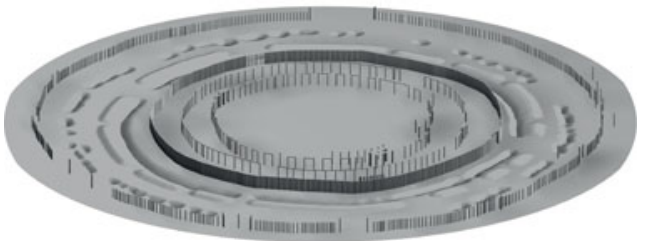

Figure 8. Layers of meaning of the Pömmelte enclosure as deduced from the archaeological record (design by André Spatzier). the finds and features. The long-term stability of these connotations must be emphasised. As with the tradition of making depositions, these meanings were valid from the start of the occupationc. $2300 \mathrm{BC}$ - until at least the early period following the deconstruction event, c. 2050 BC. While the spatial organisation and the solar alignment of the main entrances were maintained throughout the main occupation, stone axes and 'formal' graves indicate the continuation of the spatial concepts described above until the twentieth to nineteenth centuries BC.

These layers of meaning mirror parallel concepts of space including, although not necessarily restricted to, the formation of group identities (see Hansen \& Meyer 2013: 5). They can perhaps be better understood as a 'cosmological geography' manifested in the symbolism of superimposed levels of conceptual ideas related to space and to certain cardinal points (Figure 8). This idea is closely related to Eliade's (1959: 29-36) understanding of "organized - hence comicized-territory", that is territory consecrated to provide orientation within the homogeneity of the chaotic 'outside world', and the equivalence of spatial consecration and cosmogony. Put differently, the Pömmelte enclosure can be interpreted as a man-made metaphor and an icon of the cosmos, reflecting the Weltanschauung (a comprehensive conception of the world) of the people who built and used it. By bringing together Eliade and Rappaport's ideas of meaningfulness in relation to religious experience (Rappaport 1999: 391-95), it may be argued that Pömmelte was a place intended to induce oneness with the cosmos. In combining multiple layers that symbolically represent different aspects of life (first-ordermeaning), the enclosure became an icon

(C) Antiquity Publications Ltd, 2018 
metaphorically representing the world (second-order-meaning). As this icon was the place to reaffirm life symbolism ritually, through their actions, people perhaps experienced a sense of rootedness in, or unity with, the cosmos (highest-order-meaning). Although we can only speculate about the perceptions of ancient people, such a theory aiming to describe general principles of religious experience can provide insight.

Similarly, in applying a warranting model perspective, Byers (1998: 138-39) concluded that the Hopewell embankment earthworks in the north-eastern USA represent, invoke and present the authority of the sacred cosmos. If we accept this hypothesis, we can interpret structures such as the Pömmelte enclosure as monumental warrants to legitimise community - that is, as representations of the foundation upon which society constituted itself. How lower level and even profane functions (e.g. competition, jurisdiction, trade and defence) were integrated can be explained by the concept of structured multi-functionality (Spatzier 2017a: 266-68), which allows for a multi-causal, hierarchical and relational interpretation.

\section{Synopsis and prospect}

The circular enclosure of Pömmelte is the first Central European monumental complex of primarily sacred importance that has been excavated and studied in detail. It reveals aspects of society and belief during the transition from the Final Neolithic to the Early Bronze Age, in the second half of the third millennium BC. Furthermore, it offers details of ritual behaviour and the way that people organised their landscape. A sacred interior was separated from the profane environment, and served as a venue for rites that secured the continuity of the social, spiritual and cosmic order. Ancestor worship formed another integral part of this: a mound-covered burial hut and a square-shaped ditch sanctuary (located, respectively, within and near the enclosure's south-eastern sector; cf. Figure 2) - dating to 2880-2580 cal BC and attributed to the Corded Ware Culture (Spatzier 2017a: 235-44) — suggest that this site was deliberately chosen. With construction of the ring sanctuary, this place gained an immense expansion in meaning-comparable to Stonehenge. Through architectural transformation, both of these sites developed into sanctuaries with increasingly complex religious functions, including in relation to the cult of the dead. The cosmological and social functions, and the powerful symbolism of the Nebra sky disc and hoard (Meller 2010: 59-70), are reflected in Pömmelte's monumental architecture.

All of these features-along with Pömmelte's dating, function and complex ring structure-are well documented for British henge monuments (Harding 2003; Gibson 2005). The continuous use of circular enclosures in Central Europe from around 3000$1500 \mathrm{BC}$ remains to be confirmed, but strong evidence indicates usage spanning from the fifth to the first millennia BC (Spatzier 2017a: 273-96). From 2500 BC onwards, examples in Central Europe, Iberia and Bulgaria (Bertemes 2002; Escudero Carrillo et al. 2017) suggest a Europe-wide concept of sanctuary. This indicates that in extensive communication networks at the beginning of bronze metallurgy (Bertemes 2016), intellectual and religious contents circulated alongside raw materials. The henge monuments of the British Isles are generally considered to represent a uniquely British phenomenon, unrelated to Continental (C) Antiquity Publications Ltd, 2018 
Europe; this position should now be reconsidered. The uniqueness of Stonehenge lies, strictly speaking, with its monumental megalithic architecture.

Recent initiatives, such as the Stonehenge Riverside and Stonehenge Hidden Landscape Projects have made it clear that the entire area around this site must be interpreted as a complex, structured, cultural landscape (Parker Pearson 2013; Field et al. 2014). Thus, while the wooden architecture of Durrington Walls and Woodhenge, and the stone architecture of Stonehenge and Bluestonehenge were interrelated, they fulfilled different social and ritual functions. As with the Stonehenge landscape, the micro-region around Pömmelte may also reveal a 'ceremonial' division. A second Early Bronze Age enclosure with a similar layout has been excavated near Schönebeck (Spatzier 2017a: 277-79), approximately $1.3 \mathrm{~km}$ north-west of Pömmelte. Despite apparent similarities in layout, initial fieldwork shows remarkable differences in features and finds that may be explained by a differing chronology or by the diverse and perhaps dialectic meanings of the two sanctuaries. Future research will need to clarify how these sites were linked and integrated into the broader landscape.

\section{Acknowledgements}

We are thankful for project funding by the Deutsche Forschungsgemeinschaft (reference numbers 2605 and 2605/8-1), and are grateful to the reviewers for their comments and recommendations.

\section{References}

BeLl, C. 1997. Ritual perspectives and dimensions. Oxford: Oxford University Press.

Bertemes, F. 2002. Heiligtum und Kultplatz in der thrakischen Ebene im 3. Jahrtausend v. Chr. Berichte der Römisch-Germanischen Kommission 83: 118-38.

- 2009. Die Sonne und ihre Bedeutung im religiös-mythologischen Kontext der Urgeschichte Mitteleuropas, in A. Bärnreuther (ed.) Die Sonne. Brennpunkt der Kulturen der Welt: 94-126. Berlin: Minerva.

- 2016. Thinking globally about early metallurgy — resources, knowledge, and the acceleration of inequality, in H. Meller, H.P. Hahn, R. Jung \& R. Risch (ed.) Arm und Reich Zur Ressourcenverteilung in prä̈istorischen Gesellschaften (Tagungen des Landsmuseums für Vorgeschichte Halle. Band 14/I): 181-96. Halle/Saale: Landesamt für Denkmalpflege und Archäologie Sachsen-Anhalt.

Bronk Ramsey, C. 2009. Bayesian analysis of radiocarbon dates. Radiocarbon 51: 337-60. https://doi.org/10.1017/S0033822200033865

Byers, A.M. 1998. Is the Newark Circle-Octagon the Ohio Hopewell 'Rosetta Stone'? A question of archaeological interpretation, in R.C. Mainfort \& L.P. Sullivan (ed.) Ancient earthen enclosures of the Eastern Woodlands: 135-53. Gainesville: University Press of Florida.
Eliade, M. 1959. The sacred and the profane. The nature of religion. New York: Harcourt, Brace \& World.

Escudero Carrillo, J., M. Díaz-Zorita Bonilla, M. Bartelheim \& L. García Sanjuán. 2017. Chalcolithic enclosures in the Lower Guadalquivir Basin. La Loma del Real Tesoro (Carmona, Seville, Spain) and its resources, in M. Bartelheim, P. Bueno Ramírez \& M. Kunst (ed.) Key resources and sociocultural developments in the Iberian Chalcolithic: 257-72. Tübingen: Tübingen Library Publishing.

Field, D., N. Linford, M. Barber, H. Anderson-Whymark, M. Bowden, P. Topping, P. Linford, M. Авbott, P. Bryan, D. Cunliffe, C. Hardie, L. Martin, A. Payne, T. Pearson, F. Small, N. Smith, S. Soutar \& H. Winton. 2014. Analytical surveys of Stonehenge and its immediate environs, 2009-2013: part 1-the landscape and earthworks. Proceedings of the Prehistoric Society 80: 1-32. https://doi.org/10.1017/ppr.2014.6

Garrow, D. 2012. Odd deposits and average practice. A critical history of the concept of structured deposition. Archaeological Dialogues 19: 85-115. https://doi.org/10.1017/S1380203812000141

Gibson, A. 2005. Stonehenge and timber circles. Stroud: Tempus. 
Hansen, S. \& M. Meyer. 2013. 'Parallele Raumkonzepte'-Einführung in das Thema der Tagung, in S. Hansen \& M. Meyer (ed.) Parallele Raumkonzepte (Topoi-Berliner Studien der Alten Welt 16): 1-8. Berlin: de Gruyter. https://doi.org/10.1515/9783110291216

Harding, J. 2003. Henge monuments of the British Isles. Stroud: Tempus.

Kaul, F. 2004. Bronzealderens religion. Studier af den nordiske bornzealders ikonografi (Nordiske Fortidsminder B 22). Copenhagen: Kongelige Nordiske Oldskriftselskab.

Kraus, J. 2006. Die soziale Differenzierung der östlichen Aunjetitzer Kultur in den Bronzezeitstufen A2 und A3 (Saarbrücker Beitr. Altkde. 84). Bonn: Habelt.

Meller, H. 2010. Nebra: Vom Logos zum Mythos-Biografie eines Himmelsbildes, in H. Meller \& F. Bertemes (ed.) Der Griff nach den Sternen. Wie Europas Eliten zu Macht und Reichtum kamen (Tagungen des Landsmuseums für Vorgesch. Halle 5): 23-73. Halle/Saale: Landesamt für Denkmalpflege und Archäologie Sachsen-Anhalt.

- 2017. Armies in the Early Bronze Age? An alternative interpretation of Únětice Culture axe hoards. Antiquity 91: 1529-45. https://doi.org/10.15184/aqy.2017.180

Parker Pearson, M. 2013. Stonehenge. Exploring the greatest Stone Age mystery. London: Simon \& Schuster.

Peacock, D. 2013. The stone of life: querns, mills and flour production in Europe up to $c .500 \mathrm{AD}$ (Southampton Monographs in Archaeology new series 1). Southampton: Highfield.

Petrasch, J. 2012. Die mittelneolithischen Kreisgraben Anlagen in Zentraleuropa: Forschungsstand und Interpretationstheorien $\mathrm{zu}$ Funktion und Bedeutung, in F. Bertemes \& H. Meller (ed.) Neolithische Kreisgrabenanlagen in Europa (Tagungen des Landsmuseums für Vorgeschichte Halle 8): 41-66. Halle/Saale: Landesamt für Denkmalpflege und Archäologie Sachsen-Anhalt.

RAPPAPORT, R.A. 1999. Ritual and religion in the making of humanity (Cambridge Studies in Social and Cultural Anthropology 110). Cambridge: Cambridge University Press.
Reimer, P.J., E. Bard, A. Bayliss, J.W. Beck, P.G. Blackwell, C. Bronk Ramsey, C.E. Buck, H. Cheng, R.L. Edwards, M. Friedrich, P.M. Grootes, T.P. Guilderson, H. Haflidason, I. Hajdas, C. Hatté, T.J. Heaton, D.L. Hoffmann, A.G. Hogg, K.A. Hughen, K.F. Kaiser, B. Kromer, S.W. Manning, M. Niu, R.W. Reimer, D.A. Richards, E.M. Scott, J.R. Southon, R.A. Staff, C.S.M. Turney \& J. van Der Plicht. 2013. IntCal13 and Marine13 radiocarbon age calibration curves $0-50,000$ years cal BP. Radiocarbon 55: 1869-87.

https://doi.org/10.2458/azu_js_rc.55.16947

Renfrew, C. 1994. The archaeology of religion, in C. Renfrew \& E.B.W. Zubrow (ed.) The ancient mind. Elements of cognitive archaeology: 47-54. Cambridge: Cambridge University Press.

Schlosser, W. In press. Geometrisch-astronomische Bewertung der Kreisgrabenanlage von Pömmelte. Forschungsberichte des Landesmuseums für Vorgeschichte Halle 10/III.

Spatzier, A. 2015. Pom̈melte-Zackmünde-Polykultureller Sakralort oder Ortskonstanz im Heiligtum wä̈rend einer kulturellen Transformation? Ein Beitrag zur Kulturentwicklung des spä̈en 3. Jts. v. Chr. in Mitteldeutschland, in H. Meller, H.W. Arz, R. Jung \& R. Risch (ed.) 2200 BC-Ein Klimasturz als Ursache für den Zerfall der Alten Welt? (Tagungen des Landsmuseums für Vorgeschichte Halle 12/II): 793-800. Halle/Saale: Landesamt für Denkmalpflege und Archäologie Sachsen-Anhalt.

Spatzier, A. 2017a. Das endneolithisch-frühbronzezeitliche Rondell von Pömmelte-Zackmünde, Salzlandkreis, und das Rondell-Phänomen des 4.-1. Jt. v. Chr. in Mitteleuropa (Forschungsberichte des Landesmuseums für Vorgeschichte Halle 10/I-II). Halle/Saale: Landesamt für Denkmalpflege und Archäologie Sachsen-Anhalt.

$-2017 \mathrm{~b}$. The honoured and the sacrificed? Gender and violence at a sanctuary of the late $3^{\text {rd }}$ millennium $\mathrm{BC}$ in central Germany, in U. Matić \& B. Jensen (ed.) Archaeologies of gender and violence: 45-76. Oxford: Oxbow.

- 2018. Detecting deliberate fragmentation at a circular enclosure from the late $3^{\text {rd }}$ millenium BC. Calculating fragmentation and refitting analysis of ceramic finds from Pömmelte-Zackmünde, Saxony-Anhalt, Germany. Prähistorische Zeitschrift: 370-86. https://doi.org/10.1515/pz-2017-0025

Stecher, M. \& K.W. Alt. In press. Anthropologische Untersuchungen an den menschlichen Überresten aus dem Rondell Pömmelte-Zackmünde. Forschungsberichte des Landesmuseums für Vorgeschichte Halle 10/III. 
TuRner, V.W. 1969. The ritual process: structure and anti-structure. New York: Aldine.

van Gennep, A. 1909. Le rites de passage. Paris: Émile Nourry.

VANDKILDE, H. 2006. Warriors and warrior institutions in Copper Age Europe, in T. Otto, H. Thrane \& H. Vandkilde (ed.) Warfare and society. Archaeological and social anthropological perspectives: 393-422. Aarhus: Aarhus University Press.
WATTs, S.R. 2014. The symbolism of querns and millstones. AmS-Skrifter 24: 51-64.

WiERMANN, R.R. 2001. Untersuchungen zur geschlechtsund altersspezifischen Bestattungssitte der Kultur mit Schnurkeramik in Böhmen. Arch. digital 1. Freiburg: Archaeomedia.

Received: 21 June 2017; Revised: 18 January 2018; Accepted: 5 February 2018 